\title{
MOTIF DUKUNGAN RELAWAN INDEPENDEN TERHADAP ELEKTABILITAS PRABOWO-SANDI PADA PILPRES 2019: STUDI ATAS GERAKAN MILENIAL INDONESIA (GMI) YOGYAKARTA
}

\author{
Rahmat Kahfi Kurnia ${ }^{1}$, Ridho Al-Hamdi ${ }^{2}$ \\ ${ }^{1,2}$ Program Studi Ilmu Pemerintahan Universitas Muhammadiyah Yogyakarta \\ Email: afifarera5@gmail.com ${ }^{1}$, ridhoalhamdi@umy.ac.id ${ }^{2}$
}

\begin{abstract}
Abstrak
Artikel ini mengkaji tentang motif dukungan relawan independen terhadap elektabilitas Prabowo-Sandi pada Pemilihan Presiden (Pilpres) 2019. Ada tiga motif yang digunakan sebagai indikator dalam penelitian ini: motif insentif-material, motif insentifsolidaritas, dan motif insentif-idealisme. Gerakan Milenial Indonesia (GMI) dipilih sebagai obyek kasus dalam penelitian ini karena organisasi ini merupakan salah satu gerakan independen yang paling aktif di antara relawan milenial lainnya yang mengkampanyekan elektabilitas Prabowo-Sandi di Daerah Istimewa Yogyakarta (DIY). Penelitian ini bersifat kualitatif dengan menggunakan pendekatan studi kasus untuk menemukan motif dukungan GMI dalam memenangkan Prabowo - Sandi pada Pilpres 2019. Teknik yang digunakan dalam pengumpulan data adalah studi dokumentasi dan wawancara mendalam. Temuan penelitian ini menunjukkan, bahwa GMI mengkombinasikan ketiga motif tersebut dalam mendukung kandidat Prabowo-Sandi. Karena itu, motif GMI bisa juga disebut dengan motif insentif campuran atau "mix incentive motive" sebagai strateginya dalam mendukung Prabowo-Sandi. Namun demikian, motif insentif-solidaritas adalah motif yang paling sering digunakan oleh GMI dalam setiap program kampanyenya dibanding motif yang lainnya
\end{abstract}

\section{Kata Kunci:}

Motif, Pilpres 2019, GMI, Relawan Independen, Prabowo-Sandi

\begin{abstract}
This paper examines the motives of the independent volunter's support toward the electability of Prabowo-Sandi in the 2019 presidential election. There three motives which will be used as the indicators: incentive-material motive, incentive-solidarity motive, and incentive-idealism motive. The Indonesian Millennial Movement (GMI) is being the selected case of the research because this organization is one of the active independent movements among millennials which campaigns for the electability of Prabowo-Sandi to the public in Yogyakarta Special Region. It is a qualitative research by applying the case study approach to find out the motives of GMI's support in winning Prabowo-Sandi in the 2019 presidential election. Documentary and in-depth interview were utilized as the data-gathering. The finding demonstrates that GMI combines all three motives in supporting the candidate. Thus, GMI had a mix incentive
\end{abstract}


motive as its strategy to support Prabowo-Sandi. Nonetheless, incentive-solidarity motive was the most frequently applied by GMI among other motives.

\section{Keywords:}

Motive, 2019 Presidential Election, GMI, Independent Volunteer, Prabowo-Sandi

\section{Pendahuluan}

Demokrasi dilandasi dengan prinsip kedaulatan yang berada di tangan rakyat. Rakyat yang berkuasa sehingga berhak terlibat dalam aktivitas politik. Untuk mewujudkan keberadaan rakyat sebagai pemegang kekuasaan tertinggi adalah dengan melaksanakan pergantian pemimpin dengan cara pemilihan umum. Pemilihan umum merupakan salah satu wadah yang bertujuan untuk memberikan kesempatan kepada rakyat untuk menentukan siapa yang akan mewakili mereka dalam lembaga negara seperti lembaga eksekutif dan legislatif. Salah satu bentuk pelaksanaan pemilu yang demokratis yaitu pada proses pemilihan presiden dan wakil presiden secara langsung yang melibatkan rakyat untuk dapat memilih secara langsung calon presiden dan wakil presiden dengan bebas menentukan siapa saja yang akan mereka pilih. Pemilu ini dianggap sebagai tonggak sejarah mulainya kehidupan demokrasi di Indonesia dan sampai saat ini masih dinilai sebagai pemilu yang diselenggarakan dengan aman, lancar, jujur dan adil serta sangat demokratis. ${ }^{1}$

Pemilihan presiden secara langsung pertama kali dilaksanakan pada tahun 2004 dengan melibatkan masyarakat memilih secara langsung DPR, DPD, DPRD serta presiden dan wakil presiden. Pada pemilihan presiden dan wakil presiden terdapat dua kandidat calon yaitu pasangan Susilo Bambang Yudhoyono - Muhammad Yussuf Kalla dan pasangan Megawati Soekarno Putri - K.H Ahmad Hasyim Muzadi. Pada pemilu tersebut dimenangkan oleh pasangan Susilo Bambang Yudhoyono yang terpilih sebagai presiden dan Muhammad Yussuf Kalla sebagai wakil presiden pada pemilu tahun 2004. Pemilu 2009 diselenggarakan serentak pada 9 april 2009 untuk memilih 560 anggota DPR, 132 anggota DPD serta DPRD se-indonesia periode 2009-2014. Sedangkan untuk pemilihan presiden dan wakil presiden dilaksanakan 8 juli 2009 yang hanya berlangsung satu putaran. Pada pemilihan presiden dan wakil presiden tahun 2009 483.

\footnotetext{
${ }^{1}$ Miriam Budiardjo, Dasar-Dasar Ilmu Politik, edisi revisi (Jakarta: Gramedia Pustaka Utama, 2010), h.
} 
terdiri dari 3 pasangan calon, yaitu pasangan Megawati Soekarno Putri - Prabowo Subianto, Pasangan Susilo Bambang Yudhoyono - Boediono, serta Jusuf Kalla Wiranto. Pada Pilpres 2009 ini di menangkan oleh pasangan Susilo Bambang Yudhoyono - Boediono.

Pada pemilihan presiden tahun 2014 merupakan pemilihan presiden langsung ketiga di Indonesia. Pemilihan presiden tahun 2014 terdiri dari dua pasang kandidat yang akan bertarung yaitu pasangan nomor satu Prabowo Subianto - M. Hatta Rajasa kemudian pasangan nomor urut dua Joko Widodo - M. Jusuf Kalla. Dalam pemilihan presiden 2014 ini dimenangkan oleh pasangan Joko Widodo - M. Jusuf Kalla. Kemenangan tersebut sekaligus menjadi munculnya sejarah fenomena relawan politik yang mendeklarasikan diri dalam mendukung salah satu kandidat pasangan calon presiden. Diantara relawan-relawan tersebut kebanyakan merupakan relawan pendukung pasangan Joko Widodo - M. Jusuf Kalla. Pada pemilu serentak tahun 2019 berdasarkan Keputusan Mahkamah Konstitusi Nomor 14/PUU-XI/2013 tentang pelaksanaan pemilu serentak, muncul penafsiran bahwa Pemilu 2019 akan diselenggarakan dengan 5 kotak. Secara sederhana putusan itu banyak dimengerti sebagai sekedar perbedaan dalam penyelenggaraannya di mana Pemilu 2019 akan diselenggarakan secara bersamaan untuk memilih DPR, DPD, DPRD, Presiden dan Wakil Presiden. ${ }^{2}$ Pemilihan presiden tahun 2019 terdiri dari dua pasang kandidat yang akan bertarung yaitu pasangan nomor urut satu Joko Widodo - K.H. Ma'ruf Amin sebagai pasangan petahana kemudian pasangan nomor urut dua Prabowo Subianto Sandiaga Salahudin Uno.

Menariknya pada pemilu tahun 2019 ini adalah kata milenials. Milenials sering disebut-sebut dalam politik pemilihan presiden tahun 2019 karena suara kaum milenials dianggap penting karena jumlahnya yang diduga mencapai lebih dari $50 \%$ pemilih. $^{3}$ Pada konteks pemilu, kaum milenials dikategorikan sebagai pemilih muda/pemula. Menurut Undang-Undang No. 19 Tahun 2008 dalam Bab IV pasal 19 ayat 2 serta pasal 20 menyebutkan bahwa yang dimaksud dengan pemilih pemula adalah warga negara

2 Mahkamah Konstitusi RI, "PUTUSAN Nomor 14/PUU-XI/2013 Tentang Pengujian UndangUndang Nomor 42 Tahun 2008 Tentang PemilihanUmum Presiden Dan Wakil Presiden Terhadap UndangUndang Dasar Negara Republik Indonesia Tahun 1945" dalam https://www.bphn.go.id/data/documents /7.7._perkara_nomor_14-puu-2013_23_jan_2014_pemilu_presiden_(.pdf diakses 1 Juli 2019.

${ }^{3}$ Kompas. TV, "Pemilih Muda Adalah Kunci Sukses Pemilu 2019" dalam https://www.kompas.tv/article/32047/pemilih-muda-adalah-kunci-sukses-pemilu-2019 diakses 1 Juli 2019. 
Indonesia yang pada hari pemilihan atau pemungutan suara adalah Warga Negara Indonesia yang sudah genap berusia 17 tahun dana tau lebih atau sudah pernah kawin yang mempunyai hak pilih dan sebelumnya belum termasuk pemilih karena ketentuan Undang-Undang Pemilu. Hal ini ditandai dengan adanya antusiasme kaum milenials salah satunya dalam bentuk relawan (volunteer) politik untuk memberikan dukungan terhadap masing-masing calon pasangan yang didukung. Munculnya fenomena relawan politik ternyata menjadi persaingan sengit terhadap Pilpres 2019. Relawan politik yang mendukung pasangan oposisi Prabowo Subianto - Sandiaga Salahudin Uno mulai bermunculan dan menunjukkan adanya persaingan untuk menandingi relawan petahana Joko Widodo - K.H. Ma'ruf Amin.

Salah satu relawan politik independen yang terbentuk dari kaum milenials yang memiliki eksistensi dalam Pilpres 2019 adalah Gerakan Milenial Indonesia (GMI). Relawan politik ini hadir untuk memberikan dukungannya terhadap pasangan oposisi calon Presiden Prabowo Subianto dan Wakil Presiden Sandiaga Salahudin Uno karena potensi kaum milenial dirasa lebih kreatif, inovatif dan jiwa progrsif. ${ }^{4}$ GMI sudah ada di 34 provinsi dan aktif di 9 provinsi secara struktural, menurut data yang dihimpunnya telah terkumpul sebanyak 14 ribu anak muda yang merapatkan barisan untuk GMI. GMI mewadahi para anak muda untuk bersuara dalam dunia politik dan juga sebagai tempat untuk menyuarakan isi hati para anak muda membawa Indonesia lebih maju. GMI D.I Yogyakarta yang beranggotakan 250 anggota milenial Indonesia dari berbagai background kampus di Kota Yogyakarta yang berbeda-berbeda mereka terdiri dari kalangan mahasiswa aktif serta alumni mahasiwa juga bergabung ke dalam wadah pendidikan politik bagi anak muda yaitu GMI DIY. Dengan mempunyai misi untuk memberikan dukungan politik terhadap pasangan calon nomor urut 02 yaitu Prabowo Subianto - Sandiaga Salahudin Uno untuk memenangkan Pilpres 2019. Mereka bergerak untuk mengkampanyekan Prabowo - Sandi serta menyampaikan visi dan misi Prabowo - Sandi terutama di sektor lapangan pekerjaan, kesehatan dan kondisi perekonomian saat ini kepada masyarakat yang berada di Kota Jogja hingga ke pelosok D.I.Yogyakarta. ${ }^{5}$

\footnotetext{
${ }^{4}$ Gerakan Milenial Indonesia, "Petunjuk Pelaksanaan dan Petunjuk Teknis (Juklak Juknis) Gerakan Milenial Indonesia(GMI)" dalam GMI Sebuah Pemikiran (2019).

${ }^{5}$ Aris Munandar, Jubir II GMI D.I.Yogyakarta, wawancara, 10 Juli 2019.
} 
Dengan aktifnya GMI dalam dunia politik Indonesia baik ketika pemilu sampai pasca pemilu dan menunjukkan bahwa GMI konsistensinya dalam partisipasi politik sebagai relawan non partai politik di Indonesia. Hal tersebut menjadi latar belakang ketertarikan peneliti untuk melakukan peneliti mengenai bagaimana motif dukungan. Oleh karena itu tulisan ini ingin menjawab pertanyaan umum bagaimana motif dukungan GMI DIY dalam mendukung pasangan calon presiden Prabowo-Sandi pada Pilpres 2019. Berdasarkan rumusan masalah yang telah diuraikan penulis, maka tujuan yang ingin dicapai dalam penelitian ini adalahUntuk mengetahui bagaimana motif dukungan relawan independen terhadap elektabilitas Prabowo - Sandi pada Pilpres 2019 sebagai relawan politik di Indonesia. Manfaat yang diharapkan dalam penelitian ini mempunyai 2 manfaat baik secara teori maupun secara praktis. 1. Secara teoritis, hasil dari penelitian ini diharapkan bermanfaat untuk menambah pemahaman mengenai relawan independen yang ada dalam perkembangan politik di Indonesia saat ini. 2. Secara praktis, penelitian ini diharapkan dapat memberikan manfaat bagi masyarakat dengan menjelaskan perkembangan relawan independen dalam politik di Indonesia sebagai partisan non partai politik.

\section{Tinjauan Pustaka}

Dalam suatu penelitian diperlukan dukungan dari hasil-hasil penelitian yang telah ada sebelumnya yang berakaitan dengan penelitian tersebut. Peneliti sendiri mendapatkan berbagai acuan penelitian terdahulu yang menjadi pendukung penyusunan jurnal ini, antara lain sebagai berikut; Peran relawan Pro Jokowi Di DIY dalam partisipasinya sebagai Organisasi relawan di Indonesia. Pasca pemilu, Peran projo telah berubah drastis di mana status relawan projo berubah menjadi ormas. Projo tidak lagi sekedar relawan yang mencari massa untuk mendukung Jokowi. Projo telah bertransformasi menjadi organisasi yang mendukung pemerintahan. Baik dengan membantu program di mana Projo DIY membantu pemerintah dalam mengsukseskan program Indonesia Pintar, kegiatan bakti sosial dan kegiatan bantuan sosial bencana alam. Projo DIY juga menjalankan pengawasan dengan memanfaatkan struktur 
organisasi yang ada dipusat, namun tidak ada timbal balik dari pemerintah terhadap output yang keluar dari proses pengawasan. ${ }^{6}$

Jogja Independent (JOINT) merupakan sebuah gerakan sosial yang pertama kali di Kota Yogyakarta dan di Indonesia yang melakukan sebuah proses kandidasi calon perseorangan untuk mengikuti pemilihan kepala daerah. Kerelawanan menjadi pondasi gerak komunitas ini. Dalam penominasian calon, setiap warga negara Indonesia berhak mendaftarkan dirinya untuk menjadi calon walikota melalui jalur independen yang dilakukan oleh JOINT. Calon-calon tersebut hanya diminta untuk menyerahkan riwayat kehidupan, visi dan misi tanpa membatasi apa pekerjaan serta tanpa dipungut biaya seperti yang sering terjadi di partai politik. Dalam pemilihan penyeleksi, JOINT memilih beberapa orang yang berkompetensi dan berintegritas serta mau bekerja secara sukarela menjadi tim penyeleksi yang akan melaksanakan tugas uji bakal calon. Namun, pemilihan atau penunjukan para penyeleksi ini tidak melibatkan seluruh elemen yang bergabung di dalam JOINT. ${ }^{7}$

Kontestasi presidensial 2014 yang diwarnai oleh kehadiran relawan politik sebagai manifestasi dari meningkatnya partsipasi aktif warga masyarakat dalam demokrasi substasial. Penelitian ini berpendapat bahwa kebangkitan gerakan sosial telah melahirkan tradisi voluntarisme dalam politik. Relawan politik yang bergerak secara offline dan online dapat meningkatkan partisipasi publik. ${ }^{8}$ Landasan kinerja, bentuk kinerja Relawan Demokrasi (Relasi), dan kendala-kendala yang dihadapi Relawan Demokrasi (Relasi) dalam pelaksanaan Pileg tahun 2014 khususnya di Kota Banda Aceh. Penelitian ini menunjukan bahwa landasan terbentuknya program Relawan Demokrasi (Relasi) adalah partisipasi pemilih yang cenderung menurun. Mekanisme kerja yang digunakan berbeda-berbeda yaitu disesuaikan dengan situasi dan kondisi yang dibutuhkan. Secara keseluruhan anggota Relasi telah bekerja sesuai dengan fungsinya sebagai penyuluh. Kendala yang dihadapi saat sosialisasi umumnya adalah gaya bahasa, teknik, waktu, dan mental.

\footnotetext{
6 B. Nugroho, "Voluntarisme Dalam Dunia Politik" dalam Naskah Publikasi Universitas Muhammadiyah Yogykarta (2018).

7 Alhafiz Atsari, "Politik Relawan: Kandidasi Calon Perseorangan di Jogja Independent (JOINT)" dalam Naskah Publikasi Universitas Mubammadiyah Yogyakarta (2016).

8 Ustad Mangku Alam, Erisandi Arditama \&Cahyo Seftyono, "Relawan: Dari Gerakan Sosial Ke Proyek Politik" dalam Suyatno Ladiqi, Ismail Suardi Wekke \& Cahyo Seftyono (ed.)., Religion, State and Society: Exploration of Southeast Asia (Semarang: Political Science Program Department of Politics and Civics Education Universitas Negeri Semarang, 2017), h. 140-150.
} 
Selain itu, pola pikir masyarakat yang sebagian besar belum memiliki kesadaran mengenai pentingnya demokrasi. ${ }^{9}$ Analisis strategi kampanye politik Gabungan Relawan Jokowi-JK Kalimantan Timur (Kaltim) dalam pemilihan Presiden tahun 2014 di Kota Samarinda yang difokuskan pada sejarah formasi dan konfigurasi Gabungan Relawan Jokowi-JK Kaltim, strategi kampanye politik Gabungan Relawan Jokowi-JK Kaltim dalam pemilihan presiden di Kota Samarinda, strategi yang paling menentukan keberhasilan Gabungan Relawan Jokowi-JK Kaltim dalam pemilihan presiden tahun 2014 di Kota Samarinda. Strategi kampanye politik gabungan relawan Jokowi-JK Kaltim meliputi: menyatukan visi relawan, pembagian dan fungsi relawan, pendekatan persuasif serta pencitraan calon. ${ }^{10}$

Penelitian yang ditulis oleh Zamzam Muhammad Fuad tahun 2015 menjelaskan tentang bagaimana peran, kendala dan upaya Relawan Demokrasi Banyumas dalam meningkatkan partisipasi politik masyarakat pada Pemilihan Umum Legislatif 2014 di Banyumas dan implikasinya terhadap ketahanan politik Banyumas. Peran Relawan Demokrasi yaitu sebagai agen pendidikan politik dan agen pendidikan pemilu. Relawan Demokrasi Banyumas juga memiliki fungsi vital dalam membangun ketahanan politik di Banyumas. Hal ini di tunjukkan Relawan Demokrasi manakala berperan sebagai agen pendidikan politik dan pemilu. Dengan kata lain, Relawan Demokrasi Banyumas memiliki peran positif dalam mewujudkan ketahanan politik yang tangguh di Banyumas. $^{11}$

Jurnal ditulis oleh Aulia tahun 2017, menjelaskan tentang strategi pemenagan yang dilakukan oleh Relawan Ahok dalam Upaya Pemenangan Ahok-Djarot pada Pilkada DKI Jakarta 2017. Strategi kampanye politik yang dilakukan pertama yaitu, pull marketing politic dengan memotivasi masyarakat untuk berpartisipasi melalui kegiatan menarik yang dibuat, kedua pull marketing party dengan mengoptimalkan media digital untuk menyebarkan pesan-pesan politik, serta mengawasi isu yang berkembang, dan

${ }^{9}$ Nopri Hariadi, Amirullah \& Ruslan, "Analisis Kinerja Relawan Demokrasi Dalam Pemilihan Umum Legislatif Di Kota Banda Aceh” dalam Jurnal Pendidikan Pancasila dan Kewarganegaraan, Th. 28, Nomor 2, (Agustus, 2015), h. 125-129.

${ }^{10}$ Evi Kurnia Sari, "Strategi Kampanye Politik Gabungan Relawan Jokowi-Jk Kaltim Dalam Pemilihan Presiden Tahun 2014 Di Kota Samarinda" dalam eJurnal Ilmu Pemerintahan, Vol. 3 No. 4 (2015), h. 1832-1841.

${ }^{11}$ Zamzam Muhammad Fuad, "Peran Pemuda Relawan Demokrasi Dalam Meningkatkan Masyarakat Pada Pemilihan Umum Legislatif Tahun 2014 Terhadap Ketahanan Politik Wilayah (Studi Pada Relawan Banyumas, Jawa Tengah)” dalam Jurnal Ketahanan Nasional, Vol. 21 No. 2 (2015), h.23-33. 
ketiga pass marketing politik menggandeng kalangan public figure, untuk memberikan testimoni positif tentang kinerja maupun figure Ahok secara personal.

Berdasarkan penelitian-penelitian di atas, dapat disimpulkan bahwa penelitian tersebut membahas tentang strategi politik, peran gerakan relawan politik dan gerakan sosial dalam pemilu di Indonesia. Namun belum ada penelitian yang komprehensif mengenai motif dukungan relawan independen. Oleh karena itu, penelitian ini akan mengkaji tentang motif dukungan relawan independen terhadap elektabilitas PrabowoSandi pada Pilpres 2019 studi atas GMI DIY.

\section{Teori Motif Politik}

Motif adalah asal kata dari motivasi, yang dikenal sebagai motive yang berarti dorongan. Motif diartikan sebagai kekuatan yang terdapat dalam diri organisme yang mendorong untuk berbuat (driving force). Pada dasarnya motivasi berasal dari motif yang merupakan pengertian yang melingkupi penggerak, baik alasan-alasan maupun dorongan dalam diri manusia. Motif tidak berdiri sendiri, tetapi saling berkaitan dengan faktor-faktor lain, baik faktor eksternal, maunpun internal. Dalam kajian psikologi, motif dimaknai sebagai alasan seseorang yang mendasarinya untuk melakukan sesuatu. Motif bukanlah sesuatu yang tampak. Sebab, itu tersembunyi. Motif dapat diketahui, di antaranya dari pengakuan seseorang terhadap alasannya melakukan suatu tindakan. McClelland. ${ }^{12}$

Dalam dunia politik, mendapatkan kekuasaan adalah tujuan bagi para aktor politik. Kekuasaan bukan keperkasaan dan gagah-gagahan, tapi wadah dan amanah untuk memperbaiki kondisi masyarakat. Pria penguasa hakikatnya adalah manajer yang mengatur dan mengeluarkan kebijakan yang berdampak baik maupun buruk bagi masyarakat. Motif politik bukanlah suatu hal yang asing dalam dunia perpolitikan di dunia, termasuk di indonesia. Motif politik berkaitan dengan kepentingan politik individu, seperti kepentingan untuk mewujudkan negara yang adil dan makmur, kepentingan untuk mewujudkan bangsa dan masyarakat yang lebih baik, atau bahkan kepentingan untuk memperoleh dukungan masyarakat, kepentingan untuk mendapatkan

\footnotetext{
${ }^{12}$ Hamzah B.Uno, Teori Motivasi dan Pengukurannya (Jakarta: Bumi Aksara,2013).
} 
simpati publik, dan juga kepentingan untuk kekuasaan. Motif politik menurut Beck \& Sorauf terdiri dari tiga motif di antaranya:

\section{Motif Insentif Material ( Material Incentives)}

Motif ini di mana seseorang ingin mendapatkan sesuatu yang bersifat materil. Pada motif material orang yang terlibat dalam dunia politik tentu ingin mengharapkan imbalan tertentu, baik berupa uang/harta benda, jabatan/posisi tertentu lembaga negara serta program jangka pendek yang berujung pada pendapatan yang meningkat.

\section{Motif Insentif Solidaritas (Solidarity/Sosial Incentives)}

Motif ini ingin mendapatkan kehidupan sosial yang baru di mana seseorang ingin mendapatkan jaringan yang lebih luas di dalam kehidupan sosialnya kemudian jaringan tersebut menjadikannya meraih kekuatan baru demi mencapai tujuan bersama sesuai dengan kepentingan yang disepakati dalam sebuah organisasi. Motif ini biasanya diciptakan sebagai bentuk solidaritas sesama anggotanya.

\section{Motif Insentif Idealisme ( Purposive/Issued Based Insentives )}

Motif ini meyakni keinginan untuk memperjuangkan sesuatu yang bersifat ideal untuk kepentingan rakyat. Sebagai aktivitas partai harus memiliki kemampuan manajemen strategis meliputi kemampuan menerjemahkan idelogi, visi, misi, dan platform partai ke dalam program kerja yang kemudian dapat menarik minat calon pemilih mereka lantaran dianggap mewakili dan identik dengan kepentingan rakyat.

Pemerintahan dari rakyat memberikan gambaran bahwa pemerintahan yang sedang memegang kekuasaan dituntut kesadarannya bahwa pemerintahan tersebut diperoleh melalui pemilihan dari rakyat bukan dari pemberian wangsit atau kekuasaan supranatural. Definisi konseptual adalah definisi yang digunakan untuk menggambarkan secara tepat suatu fenomena yang sedang diteliti. Tujuan dari definisi konseptual dalam penelitian ini adalah menjelaskan mengenai pembatasan antara konsep yang satu dengan konsep yang lainnya, yaitu Motif Politik; Suatu dorongan atau usaha untuk menggerakan seseorang demi mencapai tujuan tertentu. Politik merupakan seni dalam meraih sebuah kekuasaan secara konstitusional maupun non konstitusional yang ditempuh setiap warga negara. 
Tabel 1 . Operasional Konsep

\begin{tabular}{|c|c|l|}
\hline Variabel & Indikator & \multicolumn{1}{c|}{ Parameter } \\
\hline \multirow{5}{*}{$\begin{array}{c}\text { Motif } \\
\text { Politk }\end{array}$} & $\begin{array}{c}\text { Motif Insentif } \\
\text { Material }\end{array}$ & $\begin{array}{l}\text { Berkenaan dengan mendekatkan diri dengan } \\
\text { aktor pemerintah maupun partai jika ingin } \\
\text { melanggengkan kekuasaan dalam } \\
\text { memperoleh kedudukan yang lebih tinggi. }\end{array}$ \\
\cline { 2 - 3 } & Solidaritas & $\begin{array}{l}\text { Berkenaan dengan kehidupan sosial baru } \\
\text { untuk mendapatkan jaringan yang baru. } \\
\text { Perasaan emosional serta moral yang } \\
\text { terbentuk pada hubungan antar individu atau } \\
\text { kelompok. }\end{array}$ \\
\cline { 2 - 3 } & Motif Insentif \\
Idealisme & $\begin{array}{l}\text { Berkenaan dengan keinginan untuk } \\
\text { memperjuangkan sesuatu yang bersifat ideal. } \\
\text { Memperjuangkan kepentingan rakyat lebih } \\
\text { utama ketimbang kepentingan pribadi. }\end{array}$ \\
\hline
\end{tabular}

Sumber : Diolah oleh penulis

\section{Metode Penelitian}

Pada penelitian ini, peneliti menggunakan metode kualitatif dengan studi kasus (case study). Penelitian ini memutuskan diri secara intensif pada satu obyek tertentu yang mempelajarinya sebagai suatu kasus. Data studi kasus dapat diperoleh dari semua pihak yang bersangkutan, dengan kata lain dalam studi kasus ini dikumpulkan dari berbagai sumber. ${ }^{13}$ Metode penelitian kualitatif dengan menggunakan pendekatan studi, penelitian berusaha menceramati dan menganalisis tentang Motif Dukungan Relawan Independen Terhadap Elektabilitas Prabowo - Sandi Pada Pilpres 2019 Studi Atas GMI DIY dengan mewawancarai narasumber yang terlibat langsung dalam Proses dukungan Gerakan relawan independen terhadap Elektabilitas Prabowo - Sandi pada Pilpres 2019 tersebut. Dengan menggunakan metode kualitatif deskriptif, maka data yang didapat akan lebih mendalam, akurat, dan bermakna sehingga tujuan dilakukannya penelitian ini dapat tercapai. Data primer diperoleh melalui informan dalam wawancara mendalam ketika di lapangan ${ }^{14}$.

Data primer yang diperoleh secara langsung dari hasil wawancara dengan narasumber. Data primer dalam penelitian ini diantaranya adalah wawawancara dengan

\footnotetext{
2003),h. 63.

13 Hadari Nawawi, Kepemimpinan Mengefektifkan Organisasi (Yogyakarta: Universitas Gajah Mada,

${ }^{14}$ Lexy Moleong, Metodologi Penelitian Kualiatif (Bandung: Remaja Rosdakarya, 2004), h. 157.
} 
koordinator GMI Yogyakarta, Juru bicara GMI Yogyakarta, Juru bicara GMI Pusat, dan Milenial GMI lainnya sehingga akan mendapatkan data yang lebih akurat. Kemudian data sekunder yang diperoleh dari sumber kedua atau sumber sekunder, yang dapat melengkapi dan membantu peneliti bila data primer terbatas atau sulit diperoleh. Sumber data sekunder dalam penelitian ini diperoleh dari sumber tertulis berupa buku, sumber dari arsip, dokumen resmi, dan dokumen pribadi. ${ }^{15}$ Kemudian teknik pegumpulan data menggunakan wawancara merupakan metode pengumpulan data yang digunakan untuk memperoleh informasi langsung dari sumbernya. ${ }^{16}$ Dan menggunakan dokumentasi bisa berbentuk tulisan, gambar atau karya-karya monumental dari seseorang. Dapat diartikan sebagai suatu catatan tertulis atau bergambar yang berkaitan dengan sesuatu hal yang tersimpan dalam berbagai bahan yang berbentuk dokumentasi. ${ }^{17}$ Kemudian teknik analisis data menggunakan Data yang telah diperoleh peneliti, nantinya akan dianalisis menggunakan teknik analisis interaktif Miles dan Huberman ${ }^{18}$ yang menyebutkan bahwa teknik ini berdiri tiga komponen, yaitu reduksi data, penyajian data, dan penarikan kesimpulan.

\section{Hasil dan Pembahasan}

Peneliti ini memaparkan lebih dalam terkait dengan motif GMI DIY dalam mendukung Prabowo - Sandi pada Pilpres 2019. Motif atau tujuan merupakan suatu usaha bagi seseorang demi mencapai sebuah tujuan yang mereka ingin kan. Untuk mengetahui motif GMI DIY penelitian ini menggunakan 3 indikator untuk mengetahui motif tersebut.

Dalam 3 indikator tersebut terdapat motif yang pertama insentif material di mana seseorang ingin mendekatkan diri kepada aktor pemerintah dan juga ingin mendapatkan kekuasaan, kemudian motif yang kedua yaitu motif insentif solidaritas di mana seseorang bergabung ke dalam sebuah wadah organisasi untuk mendapatkan jaringan yang baru dan yang terakhir yaitu motif insentif idealisme di mana seseorang yang mempertahankan idealisme nya dan juga orang-orang yang mementingkan

\footnotetext{
${ }^{15}$ Ibid, h. 157.

${ }^{16}$ Rachmat Kriyantono, Teknik Praktis Riset Komunikasi (Jakarta: Kencana Prenadamedia Group, 2006), h.100.

${ }^{17}$ Sugiyono, Metode Penelitian Kuantiatif Kualitatif dan R\&D (Bandung: Alfabeta, 2007), h. 240.

18 Pawito, Penelitian Komunikasi Kualitatif (Yogyakarta: LKiS Pelangi Aksara, 2008), h. 104.
} 
kepentingan rakyat daripada kepentingan pribadi dirinya. Hal tersebut tentunya juga didasari oleh motif seseorang yang ingin bergabung dengan organisasi GMI D.I. Yogyakarta.

Motif itu sendiri dipahami dengan pengertian suatu dorongan yang ada didalam diri seseorang untuk berusaha mendapatkan tujuan tertentu sesuai dengan apa yang diharapkan. Motif yang ada pada diri seseorang akan mewujudkan suatu perilaku yang mengarah pada tujuan yang ingin dicapainya. Dalam pembahasan ini, peneliti menggunakan teori motif politik untuk menjawab rumusan masalah dengan ingin mengetahui bagaimana motif politik didalam organisasi GMI DIY yaitu dengan menggunakan teori yang dikemukakan oleh Beck \& Sorauf.

\section{Motif Insentif Material}

Motif insentif material adalah seseorang yang mempunyai kepentingan dalam sebuah organisasi dan juga ingin mendapatkan sesuatu berupa materil dan juga ingin memperoleh sebuah jabatan. Begitu pula didalam organisasi GMI D.I Yogyakarta, setiap anggotanya mempunyai tujuan yang berbeda-beda.Dalam Organisasi GMI D.I. Yogyakarta, setiap anggota GMI memiliki motif intensif solidaritas berbeda-berbeda untuk bergabung ke dalam organisasi tersebut. Salah satu motif yang ingin didapatkan adalah mendapatkan jaringan baru dengan menjalin sebuah hubungan yang dapat menguntungkan bagi individu tersebut. "Orang yang masuk ke sebuah organisasi karena ingin mendapatkan jaringan yang baru adalah salah satu tujuan yang bagus, artinya dia punya tujuan masuk di sebuah organisasi itu. Selain memenangkan Prabowo-Sandi mendapatkan jaringan yang baru, perasaan emosional, serta moral itu adalah salah satu bonus."19

Di dalam motif insentif solidaritas, hubungan seseorang di dalam sebuah organisasi dianggap lebih penting daripada hal lain. Menurut Aris, keterlibatan seseorang dalam sebuah organisasi secara tidak langsung akan memperoleh sebuah relasi baru. Oleh karena itu secara otomatis orang yang masuk ke dalam GMI akan mendapatkan sebuah hubungan pertemanan yang kemungkinan akan berlanjut menjadi sebuah motif untuk mendapatkan sesuatu yang menguntungkan. Tujuan Aris untuk

\footnotetext{
${ }^{19}$ Aris Munandar, Jubir II GMI D.I.Yogyakarta, wawancara, 10 Juli 2019.
} 
masuk ke dalam organisasi GMI D.I.Yogyakarta selain untuk memenangkan Prabowo Sandi, Ia juga ingin mendapatkan jaringan yang baru dan perasaan emosional baru. Hal tersebut merupakan salah satu bonus yang akan didapatkan di dalam organisasi tersebut. Sebagaimana dikatakan oleh Divo Alam bahwa "Saya masuk GMI karena kepentingan individu dan bukan karena ingin mengharapkan imbalan material. Jadi kepentingan individu menurut saya banyak, bahkan mengharapkan individu juga menurut saya jadi pandangan saya mengenai hal tersebut tergantung orangnya, kalau kepentingan individu saya sebenarnya memenangkan Prabowo - Sandi dan memperbanyak relasi sebenarnya itu kepentingan individu saya masuk GMI."20

Kepentingannya untuk masuk ke dalam organisasi GMI D.I. Yogyakarta adalah kepentingan individu yang didasari oleh niat yang sejalan dengan misi organisasi tersebut. Di dalam pernyataannya, Divo menyebutkan bahwa tujuannya untuk masuk ke dalam organisasi tersebut karena ingin memenangkan pasangan calon presiden Prabowo - Sandi. Selain itu, Ia juga ingin memperbanyak relasi di dalam organisasi GMI D.I. Yogyakarta. Ia menyanggah bahwa jika keterlibatannya masuk ke dalam organisasi GMI D.I. Yogyakarta karena ingin mendapatkan suatu imbalan berupa imbalan materi.

\section{Motif Insentif Solidaritas}

Motif insentif solidaritas adalah seseorang yang mempunyai kepentingan ke dalam sebuah wadah organisasi dan juga ingin mendapatkan jaringan/link yang baru. Jaringan yang dimaksudkan adalah hubungan kedekatan yang terjalin untuk mendapatkan imbalan berupa non material, misalnya kepercayaan yang diberikan oleh orang lain atau suatu saat akan di janjikan sebuah pekerjaan yang bersifat politik. Sehingga hubungan yang dimaksud adalah relasi untuk jangka panjang. Aris Munandar dalam pernyataannya mengatakan bahwa "orang mikir politik pasti mikir sebuah imbalan dan relasi. Banyak anggota GMI yang mendekatkan diri dengan aktor pemerintah, termasuk saya. Itu merupakan salah satu tujuan yang paling besar masuk ke dalam GMI. Kalau saya pribadi, tidak ingin mendapatkan imbalan berupa materil, namun imbalan berupa non material mungkin ada. Misalnya, orang itu akan

\footnotetext{
${ }^{20}$ Divo Alam, Anggota GMI D.I.Yogyakarta, wawancara, 6 Agustus 2019.
} 
kepercayaan dengan saya, lalu suatu saat akan di janjikan sebuah pekerjaan yang bersifat politik. Jadinya relasi untuk jangka panjang."21

Seseorang yang telah melibatkan dirinya untuk berpartisipasi politik di dalam organsisasi GMI D.I Yogyakarta pasti memiliki tujuan tersendiri. Menurut hasil wawancara Aris Munandar, Ia mengatakan bahwa setiap orang yang masuk ke sebuah organisasi politik pasti mengingingan sebuah imbalan dan relasi. Ada beberapa anggota GMI yang juga mendekatkan diri nya kepada aktor pemerintah termasuk Aris Munandar sedniri. Ia mengatakan bahwa suatu harapan yang besar masuk di GMI karena ingin mendekat diri dengan aktor pemerintah sehingga dia mendapatkan suatu imbalan yang berupa non materil dan juga di janjikan mendapatkan pekerjaan yang bersifat politik.

Sebuah visi dan motif organisasi yang sesuai dengan keinginan seseorang, dapat memperngaruhi masuknya seseorang tersebut untuk ikut serta bergabung didalamnya. Sama halnya dengan yang dijelaskan oleh Bramantyo, Ia mengikuti organisasi GMI D.I.Yogyakarta karena ia melihat visi dan motif organisasi tersebut sangat jelas dengan keinginan yang ingin ia dapatkan. Menurutnya itu adalah sebuah jalan untuk menambah relasi atau menambah jaringan yang baru. Bahkan bisa juga bertemu dengan orangorang hebat dari berbagai background..$^{22}$

Berkontribusi di dalam sebuah organisasi berarti ikut serta melakukan segala aktivitas dan tujuan yang dilakukan bersama-sama dengan seluruh anggota di dalamnya. Tujuan utama GMI D.I.Yogyakarta ini sendiri adalah untuk membantu memenangkan pasangan calon presiden Prabowo-Sandi. Sama seperti alasan yang diungkapkan oleh Ardi, alasannya masuk ke dalam organisasi GMI D.I.Yogyakarta ini karena ingin berkontribusi secara langsung untuk mengkampanyekan Prabowo-Sandi, sekaligus ingin menambah wawasan dan relasi di dalamnya. Menurutnya, dengan keikutsertaanya dalam organisasi GMI D.I.Yogyakarta secara otomatis akan membawanya memperoleh sebuah relasi sekaligus pengalaman baru di dalamnya. Sebagaimana yang diutarakan Ardi Muhammad kepada penulis bahwa "Saya masuk GMI karena ingin berkontribusi secara langsung untuk mengkampanyekan Prabowo - Sandi, ingin menambah wawasan, karena saya yakin disana saya pasti akan mendapatkan relasi juga yang memiliki latar belakang yang berbeda-beda di mana saya bisa belajar banyak disana dengan teman-

${ }^{21}$ Aris Munandar, Jubir II GMI D.I.Yogyakarta, wawancara, 10 Juli 2019.

22Bramantyo Kartiko, Juru Bicara I GMI D.I.Yogyakarta, wawancara, 22 Juli 2019. 
teman baru, memberikan pengalaman yang baru di awal saya bisa menggunakan hak pilih saya."23

\section{Motif Insentif Idealisme}

Motif insentif idealisme adalah tujuan seseorang yang masuk ke sebuah organisasi murni untuk memperjuangkan hak-hak masyarakat yang bersifat ideal. Motif idealisme dalam keterlibatan organisasi politik diartikan sebagai dorongan pribadi secara sadar untuk untuk memperjuangkan ideologi organisasi yang sesuai dengan idealisme sebagai kewajiban dan tanggung jawabnya. Dalam artian, memperjuangkan kepentingan rakyat lebih utama ketimbang kepentingan pribadi. Jika tujuan anggotanya bergabung ke dalam GMI D.I.Yogyakarta memiliki motif idealisme maka organisasi tersebut akan semakin terasa berarti untuk masyarakat yang akan mementingkan kepentingan rakyat dibanding kepentingannya sendiri.

Bergabung ke dalam organisasi GMI hanya ingin memenangkan pasangan Prabowo - Sandi, selain itu Iqbal juga menginginkan sebuah relasi atau jaringan yang baru karena kodratnya manusia itu membutuhkan sebuah jaringan yang baru atau relasi. Menurut iqbal mendapatkan relasi bukan tujuan utamanya untuk bergabung ke dalam organisasi GMI DIY tetapi yang paling utama adalah karena GMI memiliki kesamaan moral satu tujuan yaitu untuk memenangkan pasangan calon presiden nomor urut $2 .^{24}$

Sebagaimana Iqbal, Lia tidak memiliki tujuan khusus untuk mendapatkan sebuah relasi melalui organisasi tersebut. Tujuannya untuk bergabung dengan organisasi GMI D.I.Yogyakarta adalah memperjuangkan niatnya untuk memenangkan pasangan calon nomer urut 02 yaitu Prabowo-Sandi. Menurut Lia, mendapatkan sebuah relasi, kenalan atau perasaan emosional yang sama itu akan terjadi menyesuaikan dengan sendirinya. Sebagaimana disampaikan kepada kepada penulis bahwa "saya masuk GMI itu benerbener saya ingin memperjuangkan apa yang saya anggap baik dan benar untuk negeri ini terlepas nantinya kita setelah masuk ke dalam komunitas itu misalnya di GMI kita mendapatkan relasi baru kah atau perasaan seperjuangan itu urusan nanti bagi saya.

23Ardi Muhammad, Wakil Koordinator GMI D.I.Yogyakarta, wawancara, 13 Juli 2019.

${ }^{24}$ Muhammad Iqbal, Anggota D.I.Yogyakarta, wawancara, 8 Agustus 2019. 
Cuma yang jelas saya punya prinsip yang harus saya perjuangkan selebihnya relasi, kenalan, perasaan emosional yang sama itu pasti akan mengikuti." 25

Berdasarkan hasil wawancara bersama Endah bahwa Ia memiliki idealisme yang kuat untuk memperjuangkan hak-hak rakyat terutama hak untuk mensejahterakan rakyat. Selain itu rakyat juga berhak mendapatkan sesuatu yang menjadi hak nya. Oleh karena itu ia harus memperjuangkan agar seluruh rakyat Indonesia mendapatkan hak nya sebagai warga Negara Indonesia ia tidak ingin kekayaan alam yang ada di negera Indonesia jatuh ke tangan asing dan ia juga sangat menginginkan sebuah perubahan pada negara ini. "Saya mempunyai idealisme yang kuat untuk memperjuangkan hak-hak masyarakat terutama hak untuk kesejahteraan rakyat. Rakyat berhak mendapatkan sesuatu yang menjadi haknya, maka dari itu saya harus memperjuangkan agar hak rakyat benar-benar sampai ke rakyat.jangan sampai hak-hak rakyat indonesia yang seharusnya di nikmati oleh rakyat indonesia jatuh ke tangan orang asing. Makanya saya sangat menginginkan sebuah perubahan pada negeri ini.",26

Senada dengan Endah, Iqbal mengatakan bahwa idealisme yang di perjuangkan oleh Iqbal adalah untuk memperjuangkan hak-hak rakyat di mana harga bahan pokok harus stabil dan juga pengegakan hukum tidak boleh tajam ke bawah tumpul ke atas. Ia juga memberikan sebuah contoh tentang kebijakan yang di anggap tidak menguntungkan bagi rakyat kecil hanya menguntung bagi sebagian kalangan dan juga kegiatan ekspor impor di indonesia yang sangat tidak menguntungkan bagi petani indonesia. Oleh karena itu idealisme Iqbal dalam bergabung ke dalam GMI adalah untuk memperjuangkan hak-hak rakyat dan juga lebih mementingkan kepentingan rakyat ketimbang kepentingan pribadi. Ia juga sangat menginginkan perubahan bagi bangsa. $^{27}$

Asmaul salah satu anggota GMI DIY mengatakan bahwa Ia sangat mempertahankan idealisme nya yang di tanam dalam diri nya. Selain itu, ia juga memenuhi panggilan jiwa nya untuk mendukung Prabowo-Sandi pada Pilpres 2019 ini. Asmaul juga mengatakan bahwa ia bergabung ke dalam GMI DIY tidak sama sekali memiliki kepentingan pribadi melainkan untuk memenangkan Prabowo - Sandi serta

${ }^{25}$ Lia Amalia, Anggota GMI D.I.Yogyakarta, wawancara, 10 Juli 2019.

${ }^{26}$ Endah Dwi Hartatik, Anggota GMI D.I.Yogyakarta, wawancara, 9 Agustus 2019.

${ }^{27}$ Muhammad Iqbal, Anggota D.I.Yogyakarta, wawancara, 8 Agustus 2019. 
memiliki niat yang tulus untuk memperjuangkan hak-hak rakyat yang berkeinginan kuat untuk ganti presiden. ${ }^{28}$

Berdasarkan data yang di peroleh bahwa GMI DIY juga memiliki motif insentif idealisme oleh karena itu Motif GMI DIY dalam mendukung Prabowo - Sandi terdapat anggota GMI DIY yang berkeinginan mempertahankan idealisme mereka dan juga berkeinginan untuk memperjuangkan hak hak rakyat.GMI DIY pada perjalannya memiliki banyak dinamika baik internal maupun eksternal. Hal tersebut telah terekam pada motif-motif yang menajadi landasan penulisan ini. Dari 3 motif politik yang menjadi acuan penelitian, motif yang paling banyak digunakan oleh anggota GMI adalah motif insentif solidaritas dan motif idealisme. Hanya beberapa orang yang menganggap bahwa ketiga motif tersebut dimiliki oleh GMI DIY.

GMI DIY telah menjadi salah satu organisasi pemuda yang memiliki motif komplit, pada hasil yang sudah diperoleh wawancara memperlihatkan bahwa motif insentif solidaritas dan motif idealisme unggul, hal ini tentu saja sangat memungkinkan untuk terjadi, semua anak GMI diisi oleh para pemuda yang notabe nya adalah mahasiswa, sehingga idealisme dan solidaritas masih sangat terjaga, mereka akan dengan tegas menjawab bahwa saya masuk GMI karena idelisme yang sama yaitu pancasila dan memperjuangkan hak rakyat, hal ini tentu saja tepat dengan motif solidaritas, sebab milenial khusunya mahasiswa tidak bisa bergerak sendiri, mereka akan mencari jaringan, pertemanan, dan massa untuk bisa bergerak dan itulah solidaritas mereka. Gambar 1. Motif Politik GMI DIY

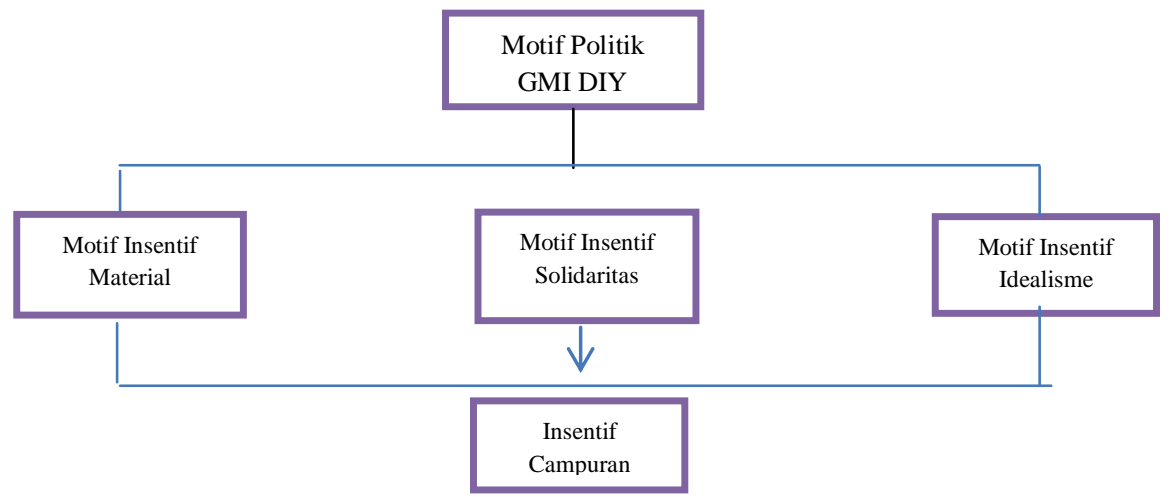

Sumber: diolah oleh penulis.

${ }^{28}$ Asmaul faradies, Anggota GMI D.I.Yogyakarta, wawancara, 10 Agustus 2019. 
Berdasakan bagan di atas, maka dapat ditarik benang merah bahwa sebenarnya GMI DIY merupakan oganisasi yang memiliki motif insentif campuran atau mix incentives, yaitu perpaduan atau kombinasi dari keseluruhan motif, terkadang motif insentif materil, kemudian insentif solidaritas dan insentif idealisme. Yang menarik dari GMI DIY adalah, ketiga motif tersebut digunakan secara bersamaan dan tidak terjadi masalah serius pada internal GMI DIY. Padahal kelemahan dari mix incentives ini adalah memungkinkan lahirnya egosenstris dan konflik internal antar anggota karena satu sama lain akan mempertahankan idealisme dan tujuan mereka.

\section{Kesimpulan}

Berdasarkan data, fakta dan informasi hasil penelitian tentang motif politik GMI DIY. Kesimpulan ini merupakan sebagai hasil temuan dan analisis data-data yang terkait dengan motif politik yang digunakan oleh GMI DIY yang dilakukan oleh beberapa anggota GMI DIY. Kesimpulan ini merujuk kepada motif politik yang dilakukan oleh GMI DIY dalam memenangkan Prabowo - Sandi pada Pilpres 2019.

Pertama, Motif Insentif Material. Pada GMI DIY motif insentif material di mana ada beberapa orang saja yang mempunyai motif insentif material tersebut yang bergabung di dalam GMI DIY termasuk juru bicara II GMI DIY yang ingin mendapatkan jabatan politik dan mendekatkan diri kepada aktor pemerintah di waktu yang akan datang. Kedua, Motif Insentif Solidaritas. Motif Solidaritas di dalam GMI DIY merupakan motif yang digunakan oleh anggota GMI DIY karena anggota GMI DIY sangat membutuhkan wadah untuk bersatu demi mencapai sebuah tujuan bersama di mana di dalamnya akan mendapatkan jaringan yang baru atau dapat membangun perasaan emosional yang baru baik antar individu maupun kelompok. Ketiga, Motif insentif Idealisme. Motif idealisme ini merupakan motif yang digunakan oleh GMI DIY dalam mendukung Prabowo - Sandi adalah untuk bergabung ke dalam sebuah organisasi politik demi mempertahankan idealisme seseorang dalam organisasi serta memperjuangkan hak-hak masyarakat di mana menurut anggota GMI DIY memperjuangkan hak hak rakyat merupakan tujuan yang sangat mulia bagi mereka dan juga menginginkan perubahan pada negeri ini.

Berdasarkan analisa di atas, motif yang paling kuat atau yang paling banyak digunakan oleh GMI DIY adalah Motif Insentif Solidaritas karena di dalam GMI DIY 
yang paling banyak bergabung adalah kalangan mahasiswa di mana mahasiswa itu sangat membutuhkan wadah untuk bersatu demi mencapai sebuah tujuan bersama di mana di dalamnya akan mendapatkan jaringan yang baru atau dapat membangun perasaan emosional yang baru.

Namun pada pandangan lain, ketiga motif tersebut telah digunakan oleh GMI DIY dan melaihrkan motif baru yang sisebut sebagai mix incentives, yaitu perpaduan atau kombinasi dari keseluruhan motif, terkadang motif insentif materil, kemudian insentif solidaritas dan insentif idealisme. Yang menarik dari GMI DIY adalah, ketiga motif tersebut digunakan secara bersamaan dan tidak terjadi masalah serius pada internal GMI DIY. Padahal kelemahan dari mix incentives ini adalah memungkinkan lahirnya egosenstris dan konflik internal antar anggota karena satu sama lain akan mempertahankan idealisme dan tujuan mereka.

\section{DAFTAR PUSTAKA}

Alam, Ustad Mangku, Erisandi Arditama \& Cahyo Seftyono. "Relawan: Dari Gerakan Sosial Ke Proyek Politik" dalam Suyatno Ladiqi, Ismail Suardi Wekke \& Cahyo Seftyono (ed.). Religion, State and Society: Exploration of Southeast Asia. Semarang: Political Science Program Department of Politics and Civics Education Universitas Negeri Semarang, 2017.

Atsari, Alhafiz. "Politik Relawan: Kandidasi Calon Perseorangan di Jogja Independent (JOINT)" dalam Naskah Publikasi Universitas Muhammadiyah Yogyakarta (2016).

Fuad, Zamzam Muhammad. "Peran Pemuda Relawan Demokrasi Dalam Meningkatkan Masyarakat Pada Pemilihan Umum Legislatif Tahun 2014 Terhadap Ketahanan Politik Wilayah (Studi Pada Relawan Banyumas, Jawa Tengah)" dalam Jurnal Ketahanan Nasional Vol. 21 No. 2 (2015), h.23-33.

Gerakan Milenial Indonesia. "Petunjuk Pelaksanaan dan Petunjuk Teknis (Juklak Juknis) Gerakan Milenial Indonesia(GMI)" dalam GMI Sebuah Pemikiran (2019).

Hariadi, Nopri, Amirullah \& Ruslan. "Analisis Kinerja Relawan Demokrasi Dalam Pemilihan Umum Legislatif Di Kota Banda Aceh" dalam Jurnal Pendidikan Pancasila dan Kewarganegaraan, Th. 28, Nomor 2, (Agustus, 2015). h. 125129. 
Kompas. TV. "Pemilih Muda Adalah Kunci Sukses Pemilu 2019" dalam https://www.kompas.tv/article/32047/pemilih-muda-adalah-kunci-suksespemilu-2019 diakses 1 Juli 2019.

Kriyantono, Rachmat. Teknik Praktis Riset Komunikasi. Jakarta: Kencana Prenadamedia Group, 2006.

Mahkamah Konstitusi RI. "PUTUSAN Nomor 14/PUU-XI/2013 Tentang Pengujian Undang-Undang Nomor 42 Tahun 2008 Tentang PemilihanUmum Presiden Dan Wakil Presiden Terhadap Undang-Undang Dasar Negara Republik Indonesia Tahun 1945" dalam https://www.bphn.go.id/data/documents 17.7._perkara_nomor_14-puu-2013_23_jan_2014_pemilu_presiden_(.pdf diakses 1 Juli 2019.

Miriam Budiardjo. Dasar-Dasar Ilmu Politik, edisi revisi. Jakarta: Gramedia Pustaka Utama, 2010.

Moleong, Lexy. Metodologi Penelitian Kualiatif. Bandung: Remaja Rosdakarya, 2004.

Nawawi, Hadari. Kepemimpinan Mengefektifkan Organisasi. Yogyakarta: Universitas Gajah Mada, 2003.

Nugroho, B. "Voluntarisme Dalam Dunia Politik" dalam Naskah Publikasi Universitas Muhammadiyah Yogykarta (2018).

Pawito. Penelitian Komunikasi Kualitatif. Yogyakarta: LKiS Pelangi Aksara, 2008.

Sari, Evi Kurnia. "Strategi Kampanye Politik Gabungan Relawan Jokowi-Jk Kaltim Dalam Pemilihan Presiden Tahun 2014 Di Kota Samarinda" dalam eJurnal Ilmu Pemerintahan, Volume 3 No. 4 (2015), h. 1832-1841.

Sugiyono. Metode Penelitian Kuantiatif Kualitatif dan R\&D. Bandung: Alfabeta, 2007.

Uno, Hamzah B. Teori Motivasi dan Pengukurannya. Jakarta: Bumi Aksara, 2013.

\section{Wawancara}

Ardi Muhammad, Wakil Koordinator GMI D.I.Yogyakarta, wawancara, 13 Juli 2019.

Aris Munandar, Jubir II GMI D.I.Yogyakarta, wawancara, 10 Juli 2019.

Asmaul faradies, Anggota GMI D.I.Yogyakarta, wawancara, 10 Agustus 2019.

Bramantyo Kartiko, Juru Bicara I GMI D.I.Yogyakarta, wawancara, 22 Juli 2019.

Divo Alam, Anggota GMI D.I.Yogyakarta, wawancara, 6 Agustus 2019. 
Endah Dwi Hartatik, Anggota GMI D.I.Yogyakarta, wawancara, 9 Agustus 2019.

Lia Amalia, Anggota GMI D.I.Yogyakarta, wawancara, 10 Juli 2019.

Muhammad Iqbal, Anggota D.I.Yogyakarta, wawancara, 8 Agustus 2019. 